\title{
Survey of waste disposal methods in Awka metropolis
}

\section{ULAETO SARAH BILL ${ }^{1}$; NNOROM INNOCENT CHIDI ${ }^{2}$; ALISA CHRISTOPHER $\mathrm{O}^{3}$; EWUZIE UGOCHUKWU ${ }^{2}$ *}

\author{
${ }^{I}$ Department of Chemical Sciences, Rhema University, Aba, Abia State, Nigeria \\ ${ }^{2}$ Chemistry Department, Abia State University, Uturu, Abia State, Nigeria \\ ${ }^{3}$ Chemistry Department, Federal University of Technology, Owerri, Imo State, Nigeria \\ *Corresponding author: ewuzieug@gmail.com
}

KEY WORDS: Waste management, open burning, waste generation, dumpsite, Awka

\begin{abstract}
Waste disposal methods commonly practiced in Awka metropolis, Anambra state were investigated from August to October, 2013. Data was analyzed with both descriptive statistics of frequency and percentages, and alternate hypotheses were tested using Analysis of Variance (ANOVA) at a significance level of 0.05. Respondents in support of open burning were $61.2 \%$, while $2.9 \%$ took to burying waste as their preferred waste management option. Only about $34.0 \%$ of the waste generated was collected at the dumpsites within the metropolis by the waste management agency, as the participants rely on their preferred waste management options without any consideration to the associated health and environmental consequences. Statistical analysis revealed that residents of Awka believed that their waste disposal methods were safe and waste collection points were enough. The residents do not shy away from participating in disposal of waste. Majority of the respondents were of the secondary school category that engages in domestic chores. (C) JASEM
\end{abstract}

\section{http://dx.doi.org/10.4314/jasem.v19i2.19}

\section{INTRODUCTION}

Amassing waste and its management process is still a life threatening situation. Proper waste disposal methods and treatment is of great concern with respect to the quality of life and the environment we live in (Fakere et al., 2012). Adedeji (2005) revealed that the overall quality of lives of human beings, to a great extent, depends on the quality of our environment. Thus improving on environmental sanitation improves on the living conditions and health status of the populace (Fakere et al., 2012). Humans' exposure to unhealthy disposal and management of waste is responsible for a majority of health risks and disease vectors (Ogbonna et al., 2012). Various disposal methods have been investigated and reported in past literatures. Each method has its own associated health effects and risks. Burning of waste for example either in incinerators, burn pits or open air releases harmful substances like dioxins, mercury, furan and polychlorinated biphenyls into the environment. These pollutants linger for a long time and have the tendency to bio-accumulate and is absorbed indirectly through food and water. When combustion of waste is incomplete, carbon monoxide is released into the atmosphere and absorbed by the blood and the lungs (Zender, 2005). In some studies on waste disposal, Babatola (2008), Awosusi (2010) and Ogbonna et al (2012) classified hospital waste, industrial waste and some household waste as *Corresponding author: ewuzieug@gmail.com hazardous and toxic to humans, animals and even plants due to contaminated chemicals in them which could result in their being flammable, corrosive and/or explosive. Lekwot et al. (2012) also reports that hospital waste is a public health risk.

Lack of knowledge on associated health hazards resulting from improper disposal of wastes, inadequate disposal tools and methods, misuse of available waste disposal facilities creates opportunity for spread of diseases and infections of all kinds such as cholera, diarrhea and typhoid fever among others. It also encourages the infestation of flies, cockroaches and rats, devaluation of properties close to dumpsites and air pollution (Orajekwe, 2011). Burying of waste especially the non-biodegradable such as plastics and waterproofs results in leaching of harmful chemicals into the soil and eventually the groundwater. Burying waste and landfills gradually results in both air and water pollution. Separation of waste is not usually taken into consideration at all as research shows that both biodegradable and nonbiodegradable are disposed of together. Any unhealthy waste disposal method encourages scavengers to collect used materials and recycle locally without going through the approved recycling techniques and procedures to reduce the wide spread of diseases and ailments presently plaguing humanity. This study is aimed at the following: Determining the level of awareness and participation 
of residents in Awka metropolis in proper waste disposal methods. Examine the health and environmental hazards of their disposal options. Discuss proper waste disposal methods worthy of emulation.

\section{MATERIALS AND METHODS}

Description of the study area: Awka is the capital of Anambra State and is located within south-eastern Nigeria. Geographically, it lies between latitude 6.22 ${ }^{\circ} \mathrm{N}$ and longitude $7.07{ }^{\circ} \mathrm{E}$. Found within the flood plain of Udi escarpment and drains into the River Niger by the Omambara River and its existing tributaries. As part of the rainforest zone of Nigeria, Awka experiences both wet and dry seasons with an annual rainfall range of $2000-3000 \mathrm{~mm}$. Daily temperature range in the metropolis is about $22.3-$ $32.1{ }^{\circ} \mathrm{C}$ and relative humidity is about $68-79 \%$ (Onyido et al., 2014). Estimated population of total inhabitants in the capital city is about $1,130,020$ (NPC, 2006). The people of Awka are mainly Igbos with a small percentage of Hausas and Yorubas. Nnamdi Azikiwe University and Paul's University are the institutions of higher learning with about 34 secondary schools and 76 primary schools for basic and secondary education (Onyido et al., 2014).

Sampling techniques and data collection: The study exercise was carried out between August and October 2013. At the time of the survey, inhabitants were observed to dispose of waste in some parts of the streets, in water channels, and isolated areas, but general dumpsters made available were left to overflow allowing the waste materials to constitute nuisance and pollute the environment. Background information was sourced from conference papers and journals and other published reports and the research tool was self-developed with simplicity for clarity of purpose and contents. 150 copies of the research tool were distributed and only 103 copies were returned. The research tool was a questionnaire of 52 questions some of which had multiple options and a bio-data section. Some of the questions were open ended, creating opportunity for comments and contributions relative to the subject matter. Field observations were done to identify some of the dumpsites mentioned in the study and pictures were taken to support the claims reported. Locations of dumpsites extracted from the research tool include: Agu Awka, Umueze behind community primary school, Eke Awka, carriage way, Emma Nnaemeka Street Awka, Amawbia, Umubelu Awka.

Data analysis procedure: Data obtained from the study were analyzed by descriptive statistics using frequency and percentages. Alternate hypotheses derived from the study were analyzed using Microsoft Office Excel 2007 ANOVA.

\section{RESULTS AND DISCUSSIONS}

Socio-economic profile of respondents:

Socioeconomic study and analytical data including age, gender, marital status and educational level of respondents were presented in Figure 1.

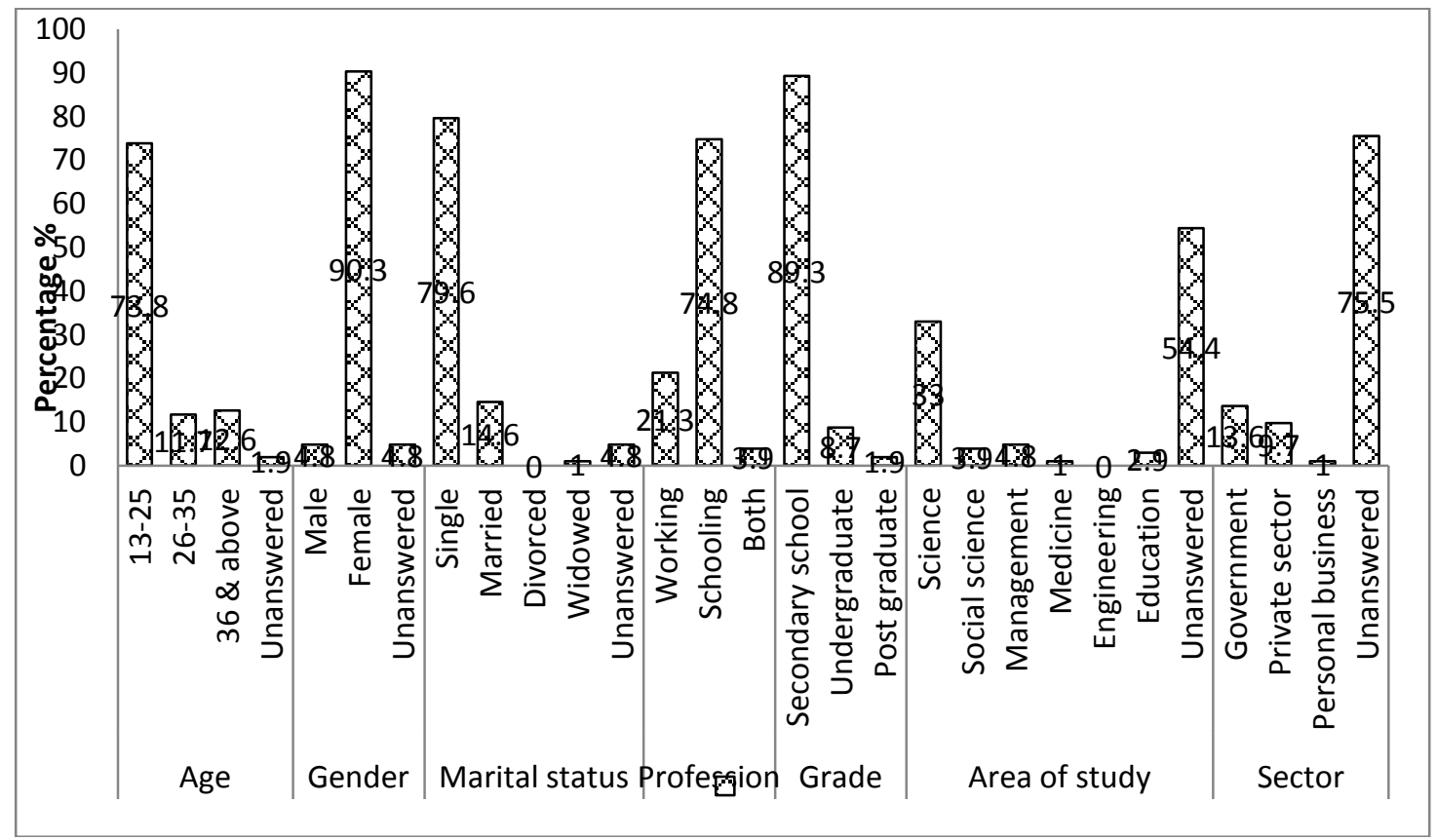

Fig 1. Socio-economic profile of respondents on waste disposal methods in Awka $(n=103)$ 
$90.3 \%$ of respondents were females with $73.8 \%$ within 13-25 years of age. $89.3 \%$ were undergoing secondary education and only $21.3 \%$ were working. About $14.6 \%$ were married amongst the respondents with $79.6 \%$ being single and $33 \%$ science inclined. Amongst those schooling, the $89.3 \%$ secondary school category of individuals were believed to be those that run errands and carry out daily house cleaning duties for their parents and/or guardians, mostly as part of their upbringing or training experience. This aspect is unique to this study. Also since the percentage of females to males is higher, the females of secondary school category from the findings were mostly responsible for the refuse disposal than their male counterparts. Field work observations reveal that majority of the waste disposed of at the central waste bins and sites are domestic waste comprising of biodegradable food waste and cartons. The non-biodegradable cartons, waterproof packages, plastic bottles of water and beverages were not left out. The household food wastes produce a substantial amount of greenhouse gases (Lyndhurst, 2009).

Waste disposal methods employed by respondents: The research tool revealed the common waste disposal methods practiced. The investigative outcome enabled the classification into: (i) burning (ii) burying and (iii) baggage for proper disposal as presented in Figure 2.

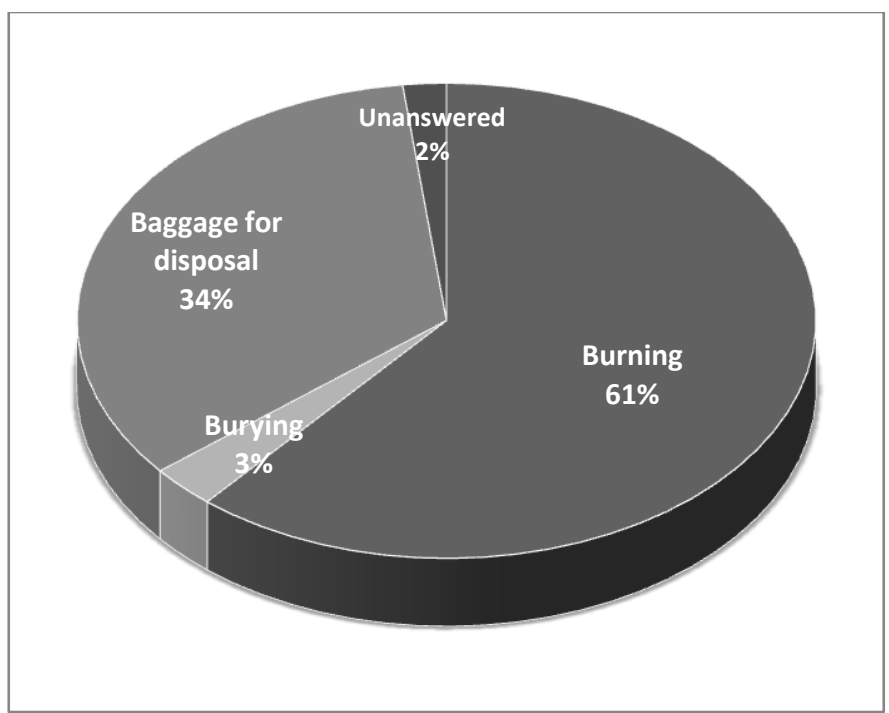

Fig 2. Waste disposal methods in School/Office premises of Awka metropolis

Quantity of daily waste is dependent on lifestyle, eating habits, living standards (Orajekwe, 2011), nature of business, school activities etc. The percentage $(34.0 \%)$ of waste baggage for disposal was low compared to the percentage of burnt waste. This revealed the preference of burning to use of the central bins. Results also revealed that waste generated in offices and schools was mostly combustible. These combustible combined waste releases a lot of particulate matter alongside the smoke. Low exposures to smokes, particulate matter and toxins of burnt waste appear harmless but after about twenty years of continuous exposure diseases like emphysema, some forms of cancer and bronchitis are seen (Zender, 2005). However, what happens to the non-combustible part like the liquid waste and food waste? Poor management produces breeding sites for vermin, air pollution and encourages growth of disease causing microbes (Orajekwe, 2011). The constant burning of waste reduces the amount of oxygen in the atmosphere; as a result, less oxygen is breathed in by residents of the affected environments. This could lead to infection of the lungs, damage to nervous system, kidney, liver etc. if not immediately then later on in life. It should be noted that children in these environments are at greater risk (Zender, 2005).

Safe practices for waste disposal: Safe practices in waste disposal are without doubt, an important aspect in our waste disposal methods. To ensure a safe and healthy life and environment certain factors are considered necessary. Factors such as duration at which the waste is cleared to the central dumpsite, quantity of waste collected at a time, method of transporting the waste to the central dumpsites, provision of sizeable waste bins at collection points etc. are taken into consideration.

Findings revealed that $42.7 \%$ of waste was largely collected at the public bins or designated disposal points within the metropolis. From the pictures taken, 
waste bins in use for public collection were small in size. Clearing of these waste materials by the waste management agency has been reported by $31.1 \%$ to be once a week and $12.6 \%$ of respondents said its once a month. This gives room for the bins to overflow with waste encouraging people to dump their refuse on the ground at the respective locations. Similar findings were reported by Awosusi (2010) with $25.0 \%$ in support of once a week clearance and $27.5 \%$ for once a month. $57.3 \%$ agree that there are enough waste collection points in the metropolis. $45.6 \%$ report that the waste was allowed to overflow before they were cleared and $29.1 \%$ agreed that residents also dumped the extras on the ground. 14.6 $\%$ agreed that the collection points were close to the roads. This is likely to cause road traffic, block the gutters close by, is a mess to public view and associated health hazards is of great concern (Fafioye and John-Dewole, 2013). The indifferent attitude of a people towards waste disposal is an expression of their internal behavior resulting from socio-cultural orientation and transition (Afangideh et al., 2012).

Data analysis and test of significance: Microsoft Office Excel 2007 Analysis of variance (ANOVA) was used to analyze the data and test the significance of hypotheses obtained from the study. Significance as seen in F-calculated, F-critical and p-values are reported in Table 1. Significance level of 0.05 is used in this study

Table 1. Statistical analysis and test of significance of Awka waste disposal survey $(n=103)$

\begin{tabular}{lcccc}
\multicolumn{1}{c}{ Hypotheses } & \multicolumn{4}{c}{ Significance } \\
& Fcal & P-value & Fcrit & Reamark \\
\hline $\begin{array}{l}\text { 1. Management of waste leads to proper } \\
\text { disposal }\end{array}$ & 4.85 & 0.01 & 3.05 & reject \\
$\begin{array}{l}\text { 2. Awka metropolis has enough waste } \\
\text { collection points }\end{array}$ & 1.58 & 0.25 & 3.48 & accept \\
$\begin{array}{l}\text { 3. The disposal methods practiced are safe } \\
\text { enough }\end{array}$ & 0.32 & 0.86 & 2.87 & accept \\
$\begin{array}{l}\text { 4. Residents of Awka shy away from } \\
\text { participating in disposal of waste }\end{array}$ & 14.21 & 0.01 & 5.19 & reject \\
\hline
\end{tabular}

Hypothesis 1: Management of waste leads to proper disposal.The analysis revealed that the calculated Fcalculated value of 4.85 was greater than the Fcritical value of 3.05. P-value obtained was 0.01 and was less than the level of significance. This showed that it was therefore insignificant and the null hypothesis was rejected retaining the alternate hypothesis. Thus, management of waste does not lead to proper disposal.

Hypothesis 2: Awka metropolis has enough waste collection points. The F-calculated value of 1.58 was less than the F-critical value of 3.48. P-value of 0.25 was greater than 0.05 and was significant. The interpretation therefore accepts the null hypothesis that Awka metropolis has enough waste collection points.

Hypothesis 3: The disposal methods practiced are safe enough:P-value of 0.86 was much greater than 0.05 significance level. F-calculated (0.32) was less than F-critical (2.87). Thus, the null hypothesis was accepted that the disposal methods practiced are safe enough.

Hypothesis 4: Residents of Awka shy away from participation of disposal of waste. P-value here was insignificant at 0.01.The F-calculated value of 14.21 was greater than the F-critical value of 5.19. The null hypothesis was rejected and the alternate hypothesis was retained as residents of Awka do not shy away from participation in disposal of waste.

Conclusions and Recommendations: Analysis of data obtained from the study in Awka metropolis showed that the waste management style practiced did not lead to proper disposal. The residents seemed to have a fair knowledge of some appropriate waste disposal methods but did not practice them in totality. This was captured from their personal contributions to the study questionnaires. They include: increase in the number of waste collection sites should be made available. Strict laws on punishments for offenders should be put in place. Cleaning waste collection sites on a weekly basis and daily basis or as the need arises, and consideration of recycling practices. Waste bins should not overflow before they are cleared. Covered carriage of waste should be continued to avoid redistribution along the roads when transporting the waste to the landfill sites. Dumpsite managers should be employed to regularly inspect the temporary dumpsites and bins during clearing and cleanup.

Waste management style for a healthy life and environment is an essential consideration for a healthy people. To improve waste collection and disposal services, awareness campaigns for safe and 
appropriate waste disposal methods should be carried out. Various economic sectors in the metropolis should re-evaluate their waste management options with every consciousness of the health implications. Intensive waste management monitoring should be encouraged and maintained. Location of major dumpsites should be topmost priority on the waste management scale of preference. Waste separation before disposal should be encouraged and Environmental Impact Assessment should be carried out regularly.

\section{APPENDIX}

Pictures of the aforementioned dumpsites are listed below:

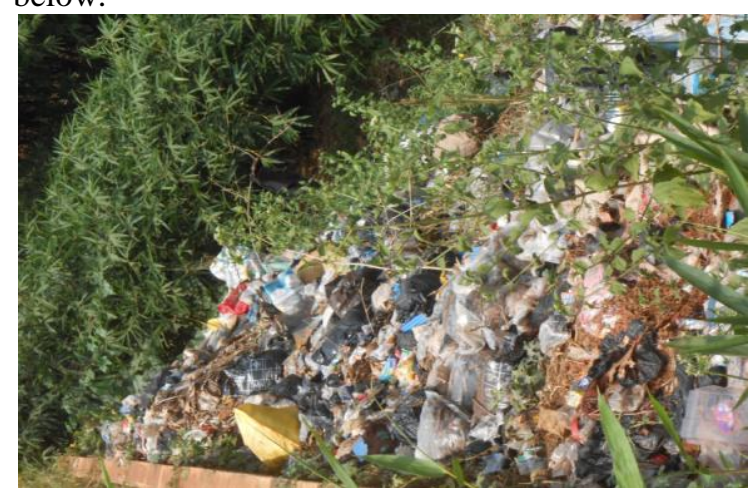

Fig. 1: Dumpsite at Agu Awka
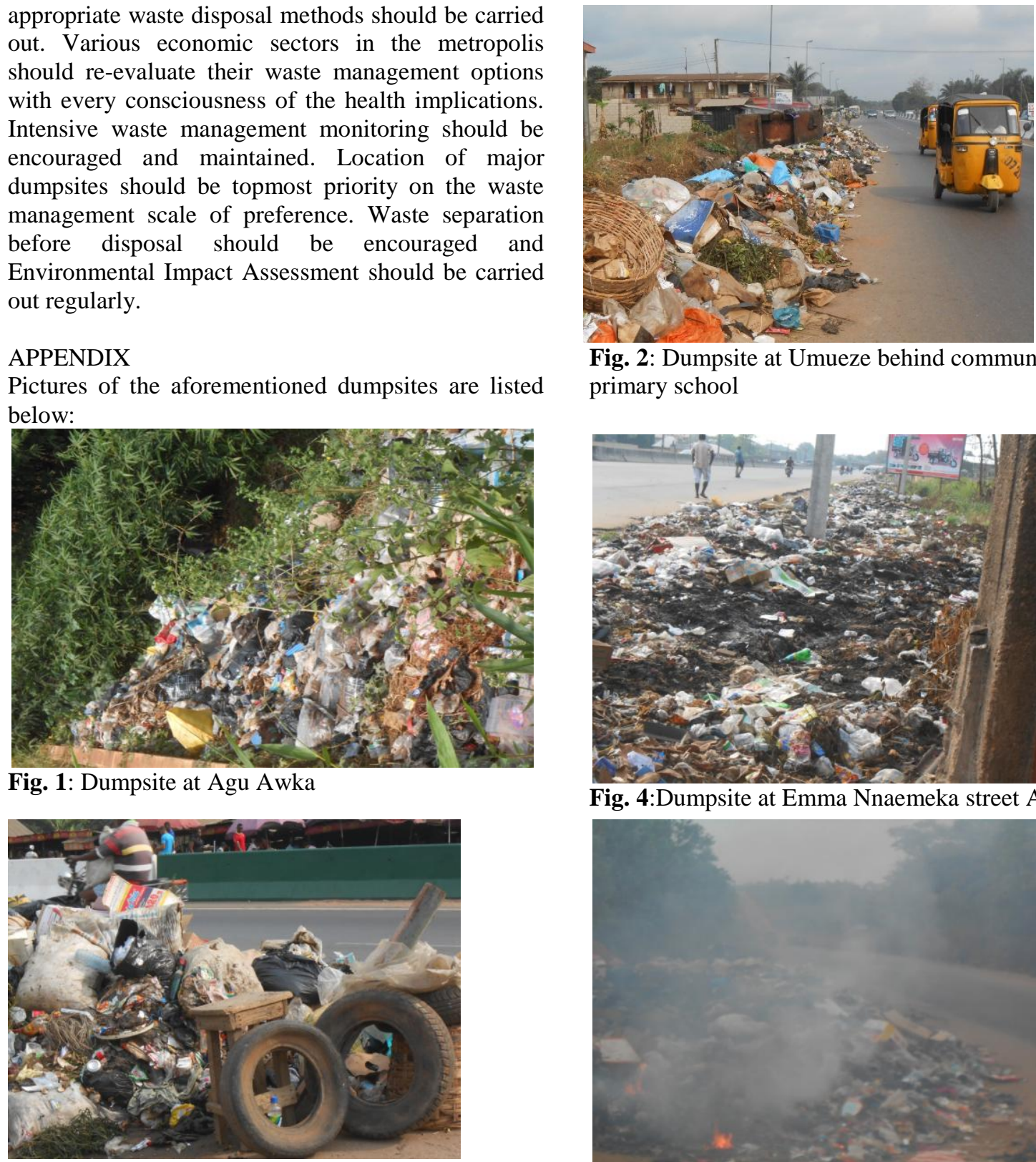

Fig. 2: Dumpsite at Umueze behind community primary school

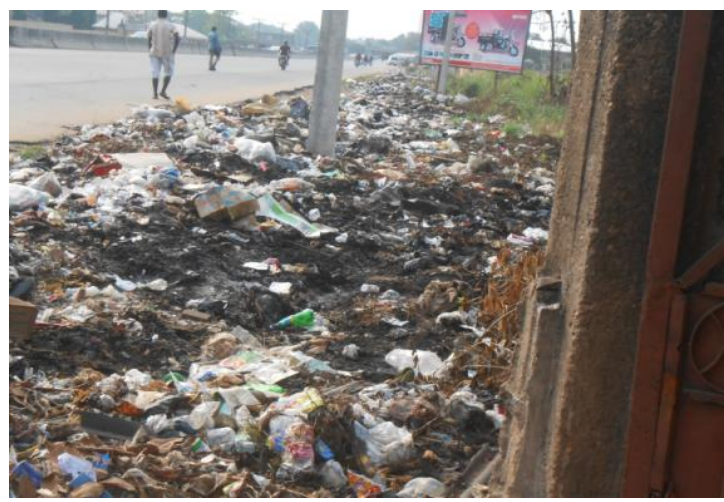

Fig. 4:Dumpsite at Emma Nnaemeka street Awka

Fig. 3: Dumpsite at Eke Awka

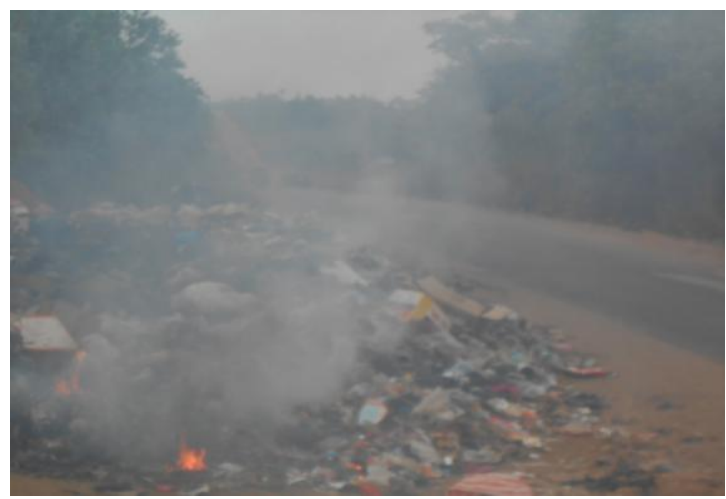

Fig. 5: Dumpsite at Amawbia

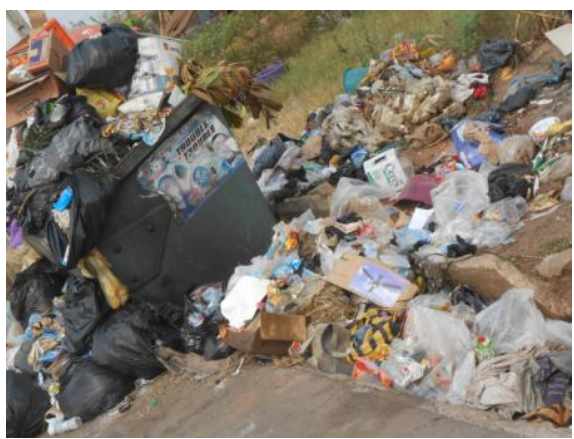

Fig. 6: Dumpsite at Umubelu Awka 


\section{REFERENCES}

Adedeji, DS; Samuel, O; Damola, D (2005). Nomadic Housing - A culture shielded from globalisation, in Fadare et al. (2005) Globalisation, Culture and the Nigerian built environment, Faculty of Environmental Design and Management, Obafemi Awolowo University, Ile-Ife, Nigeria, 2: 260-267

Afangideh, AI; Joseph, KU; Atu, JE (2012). Attitude of urban dwellers to waste disposal and management in Calabar, Nigeria. European Journal of Sustainable Development, 1(1): 22-34

Awosusi, AO (2010). Assessment of environmental problems and methods of waste management inAdo-Ekiti, Nigeria. African Research Review, 4(3b): 331-343

Babatola, JO (2008). A Study of hospital waste generation and management practice in Akure, 305

Nigeria.African Research Review, 2(3): 291-

Fafioye, OO; John-Dewole, OO (2013). A Critical assessment of waste management problems in Ibadan South-West Local Government Area, Ibadan, Nigeria. Greener journal of environm

ental and management studies, 2(2): 060-064

Fakere, AA; Fadairo, G; Oriye, O (2012). Domestic waste management and urban residential environment: Focus on Akure, Nigeria. International journal of engineering and technology, 2(5): 878-887

Lekwot, VE; Nunyi, BV; Ifeanyi, E; Okafor, CI and Adamu, B (2012). Public health implication of improper hospital waste disposal in Zonkwa district of Zangon-kataf local government area, Kaduna state. Journal of Research in Environmental Science and Toxicology, 1(2): 023-028

Lyndhurst, B (2009). Enhancing participation in kitchen waste collections. Defra Waste \& Resources Evidence Programme (WR0209). Final Project Report.

N.P.C. Nigerian National Population Census OFFICIAL GAZATTE (FGP 71/52007/2,500 (OL24) 2006 Page 2

Ogbonna, DN; Chindah, A; Ubani, N (2012). Waste management options for health care wastes in Nigeria: A case study of Port Harcourt hospitals. Journal of Public Health and Epidemiology, 4(6): 156-169

Onyido, AE; Nwangwu, UC; Aribodor, DN; Umeanaeto, PU; Ugha, CN; Ugwu, FM; Onwude, CO (2014). Bacterial Pathogens Associated with wild-caught houseflies in Awka metropololis of Anambra State, Southeastern Nigeria. New York Science Journal, 7(12): $1-8$.

Orajekwe, VN (2011). Attitude and wastes disposal habits of students of Nwafor Orizu College ofEducation Nsugbe. Journal of Research and Development, 3(1): 31-37

Zender Environmental for Institute of Environmental Professionals and CCTHITA Solid Waste Alaska Network (2005). Health Effects of Burning Trash. Accessed from www.zendergroup.org 